\title{
Catatan Penelitian
}

\section{Total Bakteri Asam Laktat, Kadar Asam Laktat, dan Warna Yogurt Drink dengan Penambahan Ekstrak Bit (Beta Vulgaris L.)}

Total Lactic Acid Bacteria, Lactic Acid Levels, and Color Yogurt Drink with Adding Extract Bit (Beta Vulgaris L.)

Fransisca Pramiarti Pasca, Nurwantoro, dan Yoyok Budi Pramono

Program Studi Teknologi Pangan, Jurusan Pertanian, Fakultas Peternakan dan Pertanian, Universitas Diponegoro Semarang Korespondensi dengan penulis (fransisca_pasca@rocketmail.com)

Artikel ini dikirim pada tanggal 12 Mei 2016 dan dinyatakan diterima tanggal 1 November 2016. Artikel ini juga dipublikasi secara online melalui www.jatp.ift.or.id. Hak cipta dilindungi undang-undang. Dilarang diperbanyak untuk tujuan komersial.

Diproduksi oleh Indonesian Food Technologists ${ }^{\circledR}$ (C2016

\section{Abstrak}

Tujuan penelitian ini adalah mengetahui jumlah total bakteri asam laktat (BAL), kadar asam laktat, dan warna pada yogurt drink dengan adanya penambahan ekstrak bit. Bahan yang digunakan berupa bit dan susu skim. Metode yang dilakukan yaitu pembuatan ekstrak bit; pembuatan starter kerja dengan kepadatan $2,5 \times 10^{9}$ $\mathrm{CFU} / \mathrm{ml}$; dan fermentasi yogurt dengan penambahan ekstrak bit diinkubasi selama 6 jam. Hasil penelitian menunjukkan penambahan esktrak bit berpengaruh nyata $(P<0,05)$ terhadap total $B A L$, kadar asam laktat, dan warna. Hasil total BAL $2,3 \times 10^{9}-1,7 \times 10^{8} \mathrm{CFU} / \mathrm{ml}$; kadar asam laktat $0,97-0,52 \%$; dan terjadi peningkatan warna ungu menjadi semakin pekat. Penambahan ekstrak bit terbaik pada $4 \%$.

Kata kunci : yogurt drink, total BAL, kadar asam laktat, warna

\section{Abstract}

The purpose of this research was to determine the amount of total $L A B$, lactic acid levels, and color of the yogurt drink with the addition of beet extract. Materials used in the form of beet and skim milk. Methods undertaken, the manufacture of beet extract; the manufacture of work starter on $2.5 \times 10^{9} \mathrm{CFU} / \mathrm{ml}$; and addition of yogurt fermented beet extracts are incubated for 6 hours. The results show the addition of the extract beet effected in $(P<0.05)$ against total $L A B$, lactic acid levels, and color. Result of total $L A B$ is $2,3 \times 10^{9}-1,7 \times 10^{8} \mathrm{CFU} / \mathrm{ml}$; lactic acid levels are 0,97-0,52\%; and an additon in the color purple become increasingly concentrated. The addition of the best extract beet happens on $4 \%$.

Keywords: yogurt drink, total of $L A B$, lactic acid levels, color

\section{Pendahuluan}

Saat ini masyarakat semakin peduli akan kesehatan. Salah satu upaya untuk menjaga kesehatan adalah pengonsumsian minuman probiotik yaitu yogurt. Yogurt merupakan produk koagulasi susu yang dihasilkan melalui proses fermentasi oleh bakteri asam laktat dengan penambahan bahan lain yang diizinkan. Yogurt memiliki banyak jenis yang dikenal dipasaran namun harus sesuai dengan standar yang ditetapkan. Salah satu jenis yogurt dipasaran adalah yogurt drink. Yogurt drink memiliki kekentalan yang rendah karena kandungan padatannya yang lebih rendah dibandingkan dengan jenis yogurt lainnya sehingga memudahkan konsumen untuk meminumnya. Yogurt memiliki berbagai manfaat yaitu bagi penderita lactose intolerance, menjaga kesehatan lambung, mencegah kanker saluran cerna (Ginting dan Pasaribu, 2005). Berbagai inovasi terus dikembangkan untuk meningkatkan nilai kesukaan yogurt yang dihasilkan. Salah satunya dengan penambahan ekstrak bit.

Bit merupakan umbi-umbian yang mengandung pemanis alami berupa sukrosa. Sukrosa memberikan rasa manis sehingga mempengaruhi penerimaan masyarakat terhadap yogurt. Umbi bit kaya akan pigmen betalain yang menghasilkan warna keunguan. Rata-rata bit mengandung betalain sebesar $380 \mathrm{mg} / 100$ $\mathrm{g}$ bobot basah (Attia et al.,2013). Hal ini memungkinkan untuk menambahkan ekstrak bit pada pembuatan yogurt, sehingga yogurt yang dihasilkan memiliki rasa manis dan warna yang menarik sehingga meningkatkan nilai kesukaannya.

Tujuan penelitian adalah untuk mengetahui jumlah total BAL, kadar asam laktat, dan organoleptik warna. pada yogurt drink dengan adanya penambahan ekstrak bit. Penelitian ini diharapkan memberikan informasi mengenai penambahan ekstrak bit terhadap karakteristik total BAL, kadar asam laktat, organoleptik warna pada yogurt drink.

\section{Materi dan Metode Materi}

Bahan yang digunakan dalam pembuatan yogurt drink dengan penambahan ekstrak bit yaitu bit (Beta vulgaris L.), air, susu skim cair, bakteri asam laktat (BAL) yaitu Lactobacillus bulgaricus, Lactobacillus acidophillus, dan Streptococcus thermophillus, Nutrient Agar (NA), alkohol, phenolpthalein (PP) $1 \%, \mathrm{NaOH} 0,1$ $\mathrm{N}$, aquadest. Alat yang digunakan dalam pembuatan yogurt drink dengan penambahan ekstrak bit yaitu pisau, juicer, gelas ukur, erlenmeyer, inkubator, refrigerator, botol kaca $500 \mathrm{ml}$, panci, kompor, termometer, mikro pipet, microtube, microtip, cawan petri, cup kecil, dan kuesioner organoleptik. 


\section{Metode}

Penelitian dilakukan pada bulan September Oktober 2015. Penelitian dirancang dengan Rancangan Acak Lengkap yang terdiri dari 5 taraf perlakuan yaitu tanpa penambahan ekstrak bit (T0), penambahan ekstrak bit $1 \%(\mathrm{~T} 1)$, penambahan ekstrak bit $2 \%(\mathrm{~T} 2)$ penambahan ekstrak bit 3\% (T3), dan penambahan ekstrak bit 4\% (T4). Penambahan ekstrak bit sebelum proses pasteurisasi dan setiap perlakuan diulang sebanyak 4 kali.

Penelitian terdiri dari beberapa langkah yaitu pembuatan ekstrak bit, pembuatan starter kerja, fermentasi yogurt drink dengan penambahan ekstrak bit, dan pengujian variable yang meliputi jumlah total bakteri asam laktat (BAL), kadar asam laktat, dan sifat organoleptik warna. Pembuatan ekstrak bit dengan cara umbi bit diambil ekstraknya dengan menggunakan juicer. Starter kerja yang digunakan, dipersiapkan dengan menginokulasikan 5\% mother starter pada 37 ${ }^{\circ} \mathrm{C}$ selama 6 jam hingga diperoleh F3 atau yang disebut dengan starter kerja (Hariyanti et al., 2013). Sedangkan mekanisme pembuatan yogurt drink dengan penambahan ekstrak bit yaitu susu skim sebanyak 10 liter dibagi menjadi 20 unit masing-masing $500 \mathrm{ml}$; lalu ditambah dengan ekstrak bit sebanyak $0 \%, 1 \%, 2 \%$, $3 \%$, dan $4 \%$ dari volume susu skim (sesuai perlakuan) dan dipasteurisasi pada suhu $80{ }^{\circ} \mathrm{C}$ selama 15 detik kemudian diturunkan suhunya hingga $43^{\circ} \mathrm{C}$ pada suhu ruang; susu pasteurisasi tersebut diinokulasi dengan starter BAL sebanyak 5\% v/v dengan kepadatan 2,5 x $10^{9} \mathrm{CFU} / \mathrm{ml}$; kemudian diinkubasi dengan suhu $37^{\circ} \mathrm{C}$ selama 6 jam. Yogurt yang telah jadi disimpan pada suhu $4{ }^{\circ} \mathrm{C}$ (Legowo et al., 2009 dengan modifikasi). Yogurt drink yang telah siap, diuji dilakukan pengujian total BAL dengan cara total plate count (Jannah et al., 2014), pengujian kadar asam laktat dengan cara titrasi (Nawangsari et al., (2012), organoleptik warna menggunakan panelis (Jannah et al., 2014).

\section{Analisis Data}

Data yang diperoleh dari pengukuran total BAL, kadar asam laktat, dan kadar protein dianalisis dengan analisis diskriptif dengan Analysis of Varians (ANOVA) pada taraf $5 \%$ untuk mengetahui perbedaan perlakuan penambahan ekstrak bit terhadap total bakteri, dan kadar asam laktat. Apabila terdapat pengaruh maka dilanjutkan dengan uji lanjut Duncan (Duncan's Multi Range Test). Uji Duncan ini digunakan untuk mengetahui jenis perlakuan konsentrasi starter yang menunjukkan perbedaan secara nyata. Sedangkan untuk pengolahan data uji warna menggunakan uji non parametrik yaitu Kruskal Wallis. Apabila terdapat pengaruh maka dilanjutkan dengan uji lanjut Mann-
Whitney U. Semua data diolah dengan bantuan computer program SPSS 16.0 for windows.

\section{Hasil dan Pembahasan \\ Total BAL}

Rata-rata nilai total BAL yogurt drink dengan penambahan ekstrak bit disajikan pada Tabel. 1. Analisis total BAL menunjukkan bahwa penambahan ekstrak bit berpengaruh nyata $(P<0,05)$ terhadap nilai total BAL yogurt. Nilai tertinggi total BAL pada presentase $0 \%$ yaitu $2,3 \times 10^{9} \pm 0,06$ dan terendah pada presentase $4 \%$ yaitu $1,7 \times 10^{8} \pm 0,02$. Secara umum, semakint tinggi konsentrasi bit yang ditambahkan semakin menurunkan populasi BAL. Terjadi penurunan nilai BAL setiap penambahan ekstrak bit. Penurunan ini terjadi karena diduga BAL lebih mudah mencerna laktosa, yang merupakan habitat asli dari BAL yaitu susu.

Pada prinsipnya, proses fermentasi menguraikan laktosa menjadi asam laktat dan berbagai komponen aroma dan citarasa. Laktosa dimanfaatkan oleh BAL selama proses fermentasi dan diubah menjadi asam laktat. Streptococcus memecah laktosa susu menjadi glukosa dan galaktosa (monosakarida) kemudian Lactobacillus memetabolisme monosakarida menjadi asam laktat (Prayitno, 2006). Selain itu, diduga peningkatan jumlah persentase ekstrak bit dalam susu menyebabkan persentase laktosa menurun dan kandungan sukrosa bit tidak dapat dimanfaatkan oleh BAL. Akibatnya substrat yang digunakan oleh BAL dalam proses fermentasi semakin rendah. Walaupun mengalami penurunan, namun rata-rata nilai total $B A L$ pada yogurt dengan penambahan ekstrak bit sesuai dengan standar total bakteri BSN (SNI 01-2981-2009) yaitu $10^{7} \mathrm{CFU} / \mathrm{ml}$.

\section{Kadar Asam Laktat}

Rata-rata nilai kadar asam laktat yogurt drink dengan penambahan ekstrak bit disajikan pada Tabel. 1. Analisis terhadap nilai kadar asam laktat menunjukkan bahwa penambahan ekstrak bit berpengaruh nyata $(\mathrm{P}<0,05)$ terhadap kadar asam laktat yogurt. Kadar asam yogurt drink dengan penambahan ektrak bit yang didapatkan sesuai dengan standar BSN (SNI 01-2981-2009) yaitu 0,5\%-0,2\%. Semakin tinggi konsentrasi bit yang ditambahkan maka terjadi penurunan kadar asam laktat pada yogurt drink. Adanya pengaruh penurunan kadar asam laktat pada penambahan ekstrak bit diduga karena penambahan ekstrak bit meningkatkan volume yogurt sehingga berakibat menurunkan presentase laktosanya sehingga produksi asam laktat menurun karena ketidakmampuan BAL untuk menggunakan sukrosa bit

Tabel 1. Rata-rata Nilai Total BAL, Kadar Asam Laktat, dan warna Yogurt Drink dengan Penambahan Ekstrak Bit ( $\mathrm{n}=4)$

\begin{tabular}{lccccc}
\hline \multirow{2}{*}{ Variabel } & \multicolumn{5}{c}{ Perlakuan } \\
\cline { 2 - 6 } & $\mathrm{T} 0$ & $\mathrm{~T} 1$ & $\mathrm{~T} 2$ & $\mathrm{~T} 3$ & $\mathrm{~T}$ \\
\hline Total BAL (CFU/ml) & $2,3 \times 10^{9 \mathrm{e}} \pm 0,06$ & $1,8 \times 10^{\mathrm{g}} \pm 0,09$ & $2,9 \times 10^{8 \mathrm{c}} \pm 0,02$ & $2,8 \times 10^{80} \pm 0,01$ & $1,7 \times 10^{8 \mathrm{a}} \pm 0,02$ \\
Kadar asam laktat $(\%)$ & $0,97^{\mathrm{e}} \pm 0,02$ & $0,93^{\mathrm{d}} \pm 0,02$ & $0,83^{\mathrm{c}} \pm 0,02$ & $0,71^{\mathrm{b}} \pm 0,03$ & $0,52^{\mathrm{a}} \pm 0,03$ \\
Warna (skor) & $2,84^{\mathrm{a}} \pm 0,37$ & $3,24^{\mathrm{b}} \pm 0,44$ & $3,52^{\mathrm{c}} \pm 0,51$ & $4,00^{\mathrm{d}} \pm 0,00$ & $4,60^{\mathrm{e}} \pm 0,50$
\end{tabular}

Keterangan: Superskrip huruf kecil yang berbeda pada baris yang sama menunjukkan perbedaan nyata $(P<0,05)$ 
dan hanya mampu memanfaatkan laktosa (gula susu). Semakin sedikit jumlah dan semakin rendah kemampuan BAL memproduksi asam laktat, maka semakin rendah keasaman yang terbentuk maka semakin tinggi nilai $\mathrm{pH}$ yang dihasilkan. Aktifitas BAL mempengaruhi tingkat keasaman yogurt karena produksi metabolit berupa asam laktat (Gad et al., 2010).

\section{Sifat Organoleptik Warna}

Rata-rata nilai sifat organoleptik warna yogurt drink dengan penambahan ekstrak bit disajikan pada Tabel. 1. Analisis statistik terhadap nilai warna menunjukkan bahwa penambahan ekstrak bit berpengaruh nyata terhadap nilai warna $(P<0,05)$. Semakin meningkatnya presentase bit maka semakin pekat warna ungu yogurt yang dihasilkan. Bit kaya akan pigmen betalain yang menghasilkan warna merah violet cenderung ungu. Rata-rata bit mengandung betalain sebesar $380 \mathrm{mg} / 100 \mathrm{~g}$ bobot basah (Attia et al., 2013). Kelemahan dari pewarna alami adalah ketidakstabilan warna saat mengalami pemanasan. Betalain merupakan pewarna alami yang akan mengalami degradasi apabila dilakukan pemanasan dengan suhu diatas $40{ }^{\circ} \mathrm{C}$. Suhu dianggap faktor yang paling pada stabilitas betalain selama pemrosesan dan penyimpanan (Garci et al.,1998)

Berdasarkan semua parameter uji, kadar bit terbaik adalah $4 \%$ karena rasa yang dihasilkan tidak terlalu asam dan warna yang dihasilkan semakin ungu. Menurut penelitian Nurhossain et al. (2012) yogurt dengan penambahan jus buah lebih diterima baik dari segi kualitas maupun organoleptiknya.

\section{Kesimpulan}

Penambahan ekstrak bit paling optimal adalah pada presentase $4 \%$. Hal ini karena pada penambahan ekstrak bit sebanyak $4 \%$, nilai total BAL paling rendah, nilai kadar asam laktat paling rendah, dan warna ungu yogurt drink paling ungu.

\section{Daftar Pustaka}

Attia, Y. Gamalia., M. E. M. Moussa and E. R. Sheashea. 2013. Characterization of red pigmen extracted from red beet (Beta vulgaris L) and its potential uses as antioxidant and natural food colorants. J. Agri. Res. 91 (3): 1095-1110.
Badan Standarisasi Nasional (BSN). 2009. SNI 012981-2009. Syarat Mutu Yogurt. Standar Nasional Indonesia, Jakarta.

Gad, A.S., A.M. Kholif and A.F. Sayed. 2010. Evaluation of the nutritional value of functional yogurt resulting from combination of date palm syrup and skim milk. J. Food Technol. 5: 250259.

Garci, F.A., C.R. Reynoso, and E. Gonza. 1998. Estabilidad de las betalai'nas extrai'das del garambullo (Myrtillocactus geometrizans). J. Food Sci. and Technol. International. 4 :115120.

Ginting, N., dan E. Pasaribu. 2005. Pengaruh temperatur dalam pembuatan yogurt dari berbagai jenis susu dengan menggunakan Lactobacillus bulgaricus dan Streptococcus thermophilus. J. Agribisnis Peternakan. 1 (2): 73-77.

Hariyanti, M. D., Y. B. Pramono, dan S. Mulyani. 2013. Total asam, viskositas, dan kesukaan pada yogurt drink dengan sari buah mangga (Mangifera indica) sebagai perisa alami. J. Aplikasi Teknologi Pangan. 2 (2): 104-107.

Jannah, A. M., A. M. Legowo, Y. B. Pramono, A. N. AlBaarri, dan S. B. M. Abduh. 2014. Total bakteri asam laktat, $\mathrm{pH}$, keasaman, citarasa, dan kesukaan yogurt drink dengan penambahan ekstrak buah belimbing. J. Aplikasi Teknologi Pangan. 3 (2): 7-11.

Legowo, A. M., Kusrahayu dan S. Mulyani. 2009. IImu dan Teknologi Susu. Badan Penerbit Universitas Diponegoro, Semarang.

Nawangsari, D. N., A. M. Legowo, dan S. Mulyani. 2012. Kadar Laktosa, Keasaman, dan total bahan padat pada whey fermentasi dengan penambahan jus kacang hijau. J. Aplikasi Teknologi Pangan. 1 (1): 12-14.

Nurhossain, M., M. Fakruddin, and M. N. Islam. 2012. Development of fruit dahi (yogurt) fortified with strawberry, orange, and grapes juice. American J. Food Tech. 7 (9): 562-570.

Prayitno. 2006. Kadar asam laktat dan laktosa yogurt hasil fermentasi menggunakan berbahgai rasio jumlah sel bakteri dan presentase starter. J. Animal Production. 8 (2):131-136. 